\title{
The Biosorption of Lead from Aqueous Solutions by a Wood- immobilized Fungal Biosorbent
}

\author{
Zomesh A. Nath Maini ${ }^{1,}{ }^{*}$, Niña Therese B. Flores ${ }^{1}$, Enrico P. Muñoz ${ }^{1}$ \\ ${ }^{1}$ School of Biology, Ateneo de Manila University, Katipunan Avenue, Loyola Heights, Quezon City 1108, Philippines
}

\begin{abstract}
Lead [ $\mathrm{Pb}(\mathrm{II})]$ biosorption capacities of immobilized Talaromyces macrosporus on Moringa oleifera $\mathrm{L}$. wood were compared against pure fungal and pure $M$. oleifera biomass. A $\mathrm{Pb}$ (II) contact test of $1000 \mathrm{ug} / \mathrm{mL}$ show similar $\mathrm{Pb}$ (II) removal of non-immobilized fungal biomass (F) and powdered wood colonized with fungi (WP+F), with WP+F producing more biomass. Powdered sorbents had higher $\mathrm{Pb}$ (II) uptake compared to whole sorbents analyzed through ICP-AES, possibly due to increased surface area for $\mathrm{Pb}(\mathrm{II}) \mathrm{binding}$. FTIR analysis of the F, WP, and WP+F identified hydroxyl, amino, carbonyl, and sulfhydryl functional groups which constitute probable $\mathrm{Pb}$ (II)-affinitive binding sites. The biosorbents tested in a Continuous Flow Column (CF) adsorbed $\mathrm{Pb}(\mathrm{II})$ at 1000,2000 , and $4000 \mathrm{ug} / \mathrm{mL}$ in 30 minutes with the $\mathrm{Pb}$ (II) uptake of $\mathrm{WP}+\mathrm{F}$ producing removal efficiencies at $91-95 \%$ regardless of initial $\mathrm{Pb}$ (II) concentration. $\mathrm{WP}+\mathrm{F}$ also showed significantly higher $q$ values than powdered wood (WP) at 42.67 to $184.83 \mathrm{mg} / \mathrm{g}$ for the $\mathrm{Pb}$ (II) test concentrations. Recovery of $\mathrm{Pb}$ (II) from $\mathrm{WP}+\mathrm{F}$ yielded $99.61 \%$ of adsorbed ions from $1000 \mathrm{ug} / \mathrm{mL} \mathrm{Pb}$ (II), proving $\mathrm{Pb}$ (II) entrapment in the sorbent. This is the first study to describe biosorption capacities for T. macrosporus and M. oleifera softwood along with the wood's viability as an immobilization scaffold. These results show the potential of using T. macrosporus immobilized on M. oleifera wood as a tool for removal of $\mathrm{Pb}$ (II) in wastewater with high $\mathrm{Pb}(\mathrm{II})$ concentrations.
\end{abstract}

Keywords: Fungi, heavy metals, immobilization, biosorption, FTIR

*Correspondence to: Zomesh A. Nath Maini, School of Biology, Ateneo de Manila University, Katipunan Avenue, Loyola Heights, Quezon City 1108, Philippines; E-mail: zmaini@ ateneo.edu

Received: July 1, 2019; Accepted: November 5, 2019; Published Online: December 9, 2019

Citation: Zomesh A. Nath Maini et al., 2019. The Biosorption of Lead from Aqueous Solutions by a Wood-immobilized Fungal Biosorbent. Applied Environmental Biotechnology, vol.5(1): 12-24. http://doi.org/10.26789/AEB.2019.02.004

Copyright: The Biosorption of Lead from Aqueous Solutions by a Wood-immobilized Fungal Biosorbent.@ 2019 Zomesh A. Nath Maini et al.. This is an Open Access article distributed under the terms of the Creative Commons Attribution-Noncommercial 4.0 International License, permitting all non-commercial use, distribution, and reproduction in any medium, provided the original work is properly cited and acknowledged.

\section{Introduction}

Lead $[\mathrm{Pb}(\mathrm{II})]$ is one of the most potent and toxic heavy metal (HM) pollutants that adversely affects all biological systems (Assi et al., 2016). Its displacement into various habitats due to increased anthropogenic activities in various sectors has made $\mathrm{Pb}(\mathrm{II})$ contamination a global ecological and health problem (Wong et al., 2017). Despite efforts and policies that regulate $\mathrm{Pb}(\mathrm{II})$ in effluents, many water systems all over the world remain highly polluted with $\mathrm{Pb}$ (II) from various sources of contamination (Hauptman et al., 2017; Mirzabeygi et al., 2017). It has therefore become imperative to look for substantial ways of remediating $\mathrm{Pb}$ (II) to prevent continued toxic exposure and food chain bioaccumulation (Velkova et al., 2018).

While several conventional means of $\mathrm{Pb}$ (II) removal exist, these remain inefficient due to their high costs, low efficiency, and generation of toxic sludge (Ahluwalia and Goyal, 2007; Kapoor and Viraraghavan, 1995). These problems have opened a niche for the use of biological agents such as fungi for the rehabilitation of $\mathrm{Pb}$ (II) and various HMs (Dhankhar and Hooda, 2011) which are safer, efficient, and more costeffective (Velkova et al., 2018). One of these remediation methods is biosorption, the removal or binding of substances from aqueous substrates or solutions using various biological materials (Michalak et al., 2013).

Fungal biosorption is as a method for heavy metal (HM) removal from aqueous substrates which takes advantage of abundant affinitive functional groups of the fungal biomass for the passive sequestration of HMs (Jha et al., 2014; Dhankhar and Hooda, 2011). Several studies have explored the use of fungal biosorbents and their efficacy in the removal of various HMs in aqueous solutions (Ayangbenro and Babalola, 2017). Despite the success in the preparation and testing of fungal biosorbents, their industrial application is limited by several restrictions which include weak mechanical strength, low elasticity, cell mass separation within solid and liquid phase systems, and the difficulty of producing adequate amounts of fungal biomass at reasonable costs (Cai et al., 2016; Das and Adholeya, 2015).

These boundaries can be overcome by immobilization, a process that crosslinks the biomass of choice to a substrate which can change certain chemical characteristics to optimize biosorption capacity (Velkova et al., 2018; Zahmatkesh et al., 2018; Das and Adholeya, 2015). Immobilization has been reported by various HM biosorption studies showing increased HM removal efficiency in solutions treated with immobilized system biosorbents compared to sole microorganisms 
or substrates (Ding et al., 2019; Svobodova and Novotny, 2018). In this study, Moringa oleifera (Lam.) wood was utilized as a scaffold for the immobilization of Talaromyces macrosporus, a fungus that has been reported to have extensive $\mathrm{Pb}$ (II) removal capacities (Maini et al., 2019). To date, there is sparse literature on the efficacy of $M$. oleifera wood specifically as an immobilizing matrix for fungi nor its use and ability as a $\mathrm{Pb}$ (II)-biosorbent. Its safety, abundance, mechanical strength, little commercial value, and ease of cultivation make it a promising biomaterial for immobilization (Stohs and Hartman, 2015; Akar et al., 2007).

This study investigates the efficacy of T. macrosporus grown on $M$. oleifera wood for $\mathrm{Pb}(\mathrm{II})$ biosorption. This fungi-wood immobilized system is utilized as a biosorbent in a continuous flow column filtration system (CF) which has been studied for use in fungal biosorption (Sağ, 2001). In this system, a prepared $\mathrm{Pb}$ (II) solution of a certain concentration is ran through the packed biosorbent that ideally traps $\mathrm{Pb}$ (II) ions (Pagnanelli et al., 2009). The process is inexpensive, stable, accessible, and requires little energy input (Long et al., 2019). Ultimately, the use of immobilized fungal biosorbents may represent a cheaper, more effective alternative to the removal of $\mathrm{HMs}$ such as $\mathrm{Pb}$ (II) from contaminated waste-water compared to traditional water treatment strategies.

\section{Materials and Methods}

\subsection{Sample Collection and Maintenance of Fungal Cultures}

Moringa oleifera wood was collected from branches of felled trees in the Ateneo de Manila University, Quezon City Philippines $\left(14^{\circ} 38^{\prime} 16.5^{\prime} \mathrm{N}, 121^{\circ} 04^{\prime} 38.7^{\prime} \mathrm{E}\right)$. The collected wood was debarked, cut into $2 \times 2 \times 0.5 \mathrm{~cm}$ pieces, boiled in $\mathrm{dH}_{2} \mathrm{O}$ for $30 \mathrm{~min}$, washed with sterile $\mathrm{dH}_{2} \mathrm{O}$, then dried at $70^{\circ} \mathrm{C}$ for 16-24h (Akhtar et al., 2004; Iqbal and Saeed, 2006). The weight of all wood chips was measured using an analytical balance prior to their use as the immobilizing scaffold for the fungi (F). Talaromyces macrosporus fungal cultures used in the study were obtained from their repository at the Ateneo de Manila University (Maini et al., 2019). Fungal stock cultures were maintained on potato dextrose agar (PDA, Himedia ${ }^{\circledR}$ ) plate supplemented with $50 \mu \mathrm{g} / \mathrm{mL}$ Ampicillin (amp).

\subsection{Preparation of Wood-immobilized Fungal Biosorbent}

Talaromyces macrosporus spores diluted to $6.0 \times 10^{5}$ spores/mL in $0.1 \%$ Tween $20 /$ Phosphate-buffered saline (PBS) were used to inoculate $60 \mathrm{~mL}$ of Na/P-buffered $(\mathrm{pH}$ 6.5 ) potato dextrose broth (PDB) solution containing a maximum of three dried M. oleifera wood (WW) pieces. The PDB was sterilized at $121^{\circ} \mathrm{C}$ for 15 minutes under $1 . \mathrm{s} \mathrm{kg} / \mathrm{cm}^{2}$ pressure prior to the placement of $\mathrm{WW}$ and fungal inoculation. The PDB with the WW and the fungal inoculum was then shaken at $100 \mathrm{rpm}, 30^{\circ} \mathrm{C}$ for seven days following the protocol (Iqbal and Saeed, 2006). The resulting wood with fungi was harvested via gravity filtration using Whatman (2) filter paper and dried at $70^{\circ} \mathrm{C}$ for $16-24 \mathrm{~h}$. The dry weight of the fungal biomass immobilized within the wood was determined as the weight difference of WW before and after fungal adherence. One batch of colonized wood-fungal biomass was dried in a similar manner and pulverized using an electronic grinder into $\sim 1 \times 1 \times 1 \mathrm{~mm}$ pieces. Both the $\mathrm{WW}$, resulting freshly colonized, and dried fungal wood matrix $(\mathrm{WW}+\mathrm{F})$ were observed at 50-300x using a Leica EZ4 Stereomicroscope and were photomicrographed after. Scale bars were added to the images using ImageJ (https://imagej.nih.gov/ij/).

\subsection{Viability Test of Wood-fungal Biosorbent}

Small amounts $(0.10 \mathrm{~g})$ of dried $\mathrm{WW}+\mathrm{F}$ were placed on top of PDA plates supplemented with $50 \mu \mathrm{g} / \mathrm{mL}$ amp then stored at $30^{\circ} \mathrm{C}$ for 5 days. At the end of the incubation, the presence or absence of fungal growth was noted. These were conducted in triplicate.

\subsection{Scanning Electron Microscopy}

Scanning Electron Microscopy (SEM) was performed to check surface features of dried biosorbents. Oven-dried samples $\left(60^{\circ} \mathrm{C}, 72 \mathrm{~h}\right)$ measuring $\sim 1 \times 1 \times 1 \mathrm{~mm}$ of $\mathrm{F}, \mathrm{WW}$, and $\mathrm{WW}+\mathrm{F}$ were prepared and visualized at magnifications ranging from 100x-3000x, at Vacc $=15.0 \mathrm{k}, \mathrm{EC}=45.0 \mathrm{~mA}$, using a Hitachi TM-1000 tabletop electron microscope.

\subsection{Initial $\mathrm{Pb}(\mathrm{II})$ Contact Test (CT)}

For the initial biosorption contact test, 1.2 grams of F, WW, $\mathrm{WW}+\mathrm{F}$, powdered wood (WP), and powdered wood with immobilized fungi (WP+F) were immersed in a $1000 \mu \mathrm{g} / \mathrm{mL}$ lead nitrate $\left(\mathrm{Pb}\left(\mathrm{NO}_{3}\right)_{2}\right)$ solution $(5 \mathrm{pH})$ in separate flasks and shaken at $100 \mathrm{rpm}, 30^{\circ} \mathrm{C}$ for 60 minutes. All tests were performed in triplicate.

After treatment, all samples, including a control solution of unexposed $1000 \mu \mathrm{g} / \mathrm{mL} \mathrm{Pb}$ (II) were gravity filtered using Whatman (2) filter paper. The supernatant containing the residual lead ions were analyzed using Inductively-Coupled Plasma Atomic Emission Spectroscopy (ICP-AES) (Sriharsha et al., 2017; Iqbal and Saeed, 2006). The percentage of metal removed from the solution $(\mathrm{E}, \%)$ was calculated following Iram et al. (2015):

$$
E=\frac{\left(C_{i}-C_{f}\right)}{C_{i}} \times 100
$$

where $\mathrm{E}$ is the removal efficiency in percentage, $\mathrm{C}_{i}$ is the predetermined lead concentration $(\mu \mathrm{g} / \mathrm{mL}), \mathrm{C}_{f}$ is the final lead concentration $(\mu \mathrm{g} / \mathrm{mL})$.

\subsection{Fourier Transform Infrared Spectroscopy}

Attenuated Total Reflection-Fourier Transform Infrared Spectroscopy (ATR-FTIR) was used to identify functional groups 
and vibrational frequency changes present on dried fungal biomass, and immobilized and non-immobilized wood sorbents before and after $\mathrm{Pb}(\mathrm{II})$ treatment. The IR spectra was obtained by placing 0.1 grams of the sorbent on the metal disc of the FT-IR spectrometer (PerkinElmer, Paragon 1000). Samples were analyzed in the wavenumber range of 600 to $4000 \mathrm{~cm}^{-1}$ at 32 scans. Spectragryph (https://www.effemm2.de/spectragryph/) was utilized in the modification and generation of the spectra images.

\subsection{Continuous Flow Column Filtration Test (CF)}

For the laboratory-scale Continuous Flow Column Filtration (CF) assembly, a $240 \mathrm{~mm}$ column setup was utilized wherein 3.0 grams of $\mathrm{WP}$ and/or $\mathrm{WP}+\mathrm{F}$ were utilized as filters to adsorb $150 \mathrm{~mL}$ of 1000,2000 , and $4000 \mu \mathrm{g} / \mathrm{mL} \mathrm{Pb}\left(\mathrm{NO}_{3}\right)_{2}$ solution that cyclically ran with a flow rate of $15 \mathrm{~mL} / \mathrm{min}$ for 30 minutes. All experimental trials were done in triplicate. After the run, residual lead ions in the solution were analyzed using ICP-AES. Biosorption capacity $(q)$ was calculated following Chen et al. (2011):

$$
q=\frac{V\left(C_{i}-C_{f}\right)}{M}
$$

where $q$ is the metal uptake in $\mathrm{mg}$ metal/g of the biosorbent or the amount of lead ions per gram of dry weight of the biosorbent, $V$ as the volume of the metal solution in $\mathrm{L}, \mathrm{C}_{i}$ as the solution's initial $\mathrm{Pb}(\mathrm{II})$ concentration in $\mu \mathrm{g} / \mathrm{mL}, \mathrm{C}_{f}$ as the solution's residual $\mathrm{Pb}(\mathrm{II})$ concentration in $\mu \mathrm{g} / \mathrm{mL}$, and $M$ as the dry weight of the biosorbent in $\mathrm{g}$.

\section{8 $\mathrm{Pb}(\mathrm{II})$ Desorption from Biosorbent}

In order to verify the $\mathrm{Pb}(\mathrm{II})$ uptake of $\mathrm{WP}+\mathrm{F}$ in the $\mathrm{CF}$ test, desorption of $\mathrm{Pb}(\mathrm{II})$ ions was done by treating each of the biosorbents used in the set-up with $60 \mathrm{~mL}$ of $1.0 \mathrm{M}$ Hydrochloric acid $(\mathrm{HCl})$ solution shaken at $100 \mathrm{rpm}, 25^{\circ} \mathrm{C}$ for 60 minutes. The sorbents were removed via gravity filtration using Whatman (2) filter paper. The supernatant containing the adsorbed $\mathrm{Pb}(\mathrm{II})$, released onto the $\mathrm{HCl}$ solution, was analyzed for $\mathrm{Pb}(\mathrm{II})$ concentrations via ICP-AES. Recovery in percentage, $(\mathrm{R}, \%)$ was computed following the work of Deng et al. (2006):

$$
R=\frac{M_{d}}{M_{a}} \times 100
$$

where $\mathrm{M}_{d}$ is the amount of $\mathrm{Pb}(\mathrm{II})$ desorbed and $\mathrm{M}_{a}$ is the amount of $\mathrm{Pb}(\mathrm{II})$ adsorbed.

\subsection{Statistical Analysis}

Statistical analysis of the data was performed using OneWay Analysis of Variance (One-Way ANOVA) and Two-Way Analysis of Variance (Two-Way ANOVA) whenever applicable. Means were compared using Tukey's multiple comparisons test $(\mathrm{p}<0.05)$ and Sidak's multiple comparisons test $(\mathrm{p}<0.05)$. Significant differences between standard deviations were determined via Brown-Forsythe $(\mathrm{P}<0.05)$. All statistical tests were performed using GraphPad Prism (v6.01).

\section{Results}

\subsection{Preparation of Wood-immobilized Fungal Biosorbent}

Talaromyces macrosporus cells were immobilized on $M$. oleifera wood to generate and characterize the biosorbent. Representative microscopic and scanning electron micrographs of the wood before and after immobilization of fungi are presented in Figures 1 and $2 \mathrm{~B} \& \mathrm{C}$ respectively. Whole M. oleifera wood from Figure 1B showed numerous open pores and interstices within xylem vessels that facilitated fungal attachment to the wood. Successful colonization of the WW is seen in Figure 1C, where fungal hyphae completely encapsulated the WW after subsequent drying at $70^{\circ} \mathrm{C}$ even after grinding (Figure 1C and 2C). Microscopic examination reveals that colonization begins $48 \mathrm{~h}$ after spore inoculation, with complete coverage after 7 days.
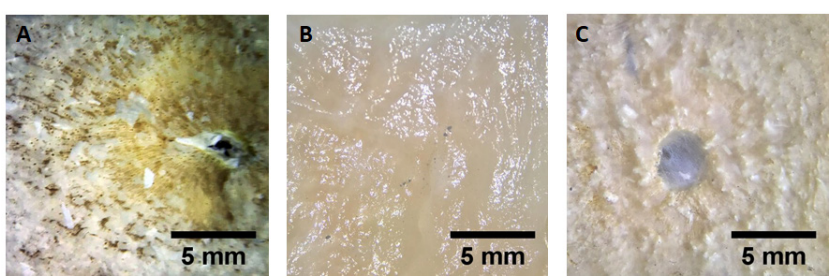

Figure 1. Various stages of the generation of the wood-immobilized fungal biosorbent. Dried uncolonized WW before immobilization of fungal hyphae (A), complete colonization after 7 days (B), dried, colonized material after $24 \mathrm{~h}$ drying, $\mathrm{WW}+\mathrm{F}(\mathrm{C})$.
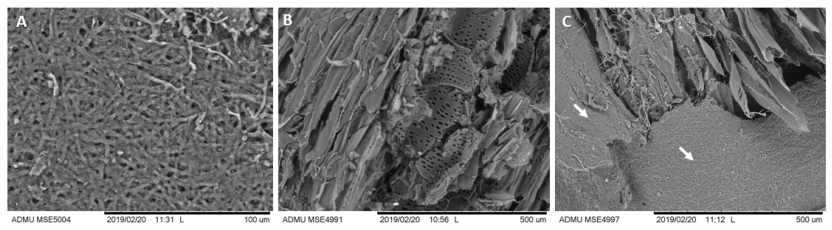

Figure 2. Surface micrographs obtained by Scanning Electron Microscopy (SEM) of (A) dried T. macrosporus with visible mycelia, F, 1000x (B) dried WW, 200x and (C) dried WW+F, 200x.

\subsection{Initial CT}

The ability of the biosorbent was determined through a contact test using $1000 \mu \mathrm{g} / \mathrm{mL} \mathrm{Pb}\left(\mathrm{NO}_{3}\right)_{2}$. Figure 3 shows a comparison of a $\mathrm{Pb}$ (II)-contact test showing the removal efficiencies of WW versus WP, with and without fungal colonization. The removal efficiency of biosorbents with immobilized fungi $(\mathrm{WW}+\mathrm{F}$ and $\mathrm{WP}+\mathrm{F})$ is significantly higher $(\mathrm{P}<0.05)$ 
than those with wood only (WW, WP). F had the highest contact removal of $\mathrm{Pb}$ (II) at $91.02 \%$ while $\mathrm{WW}$ had the lowest removal efficiency at $23.70 \%$. However, removal efficiency by $\mathrm{F}$ is not significantly different from the removal efficiency of $\mathrm{WP}+\mathrm{F}$ at $90.37 \%(\mathrm{P}<0.05)$.

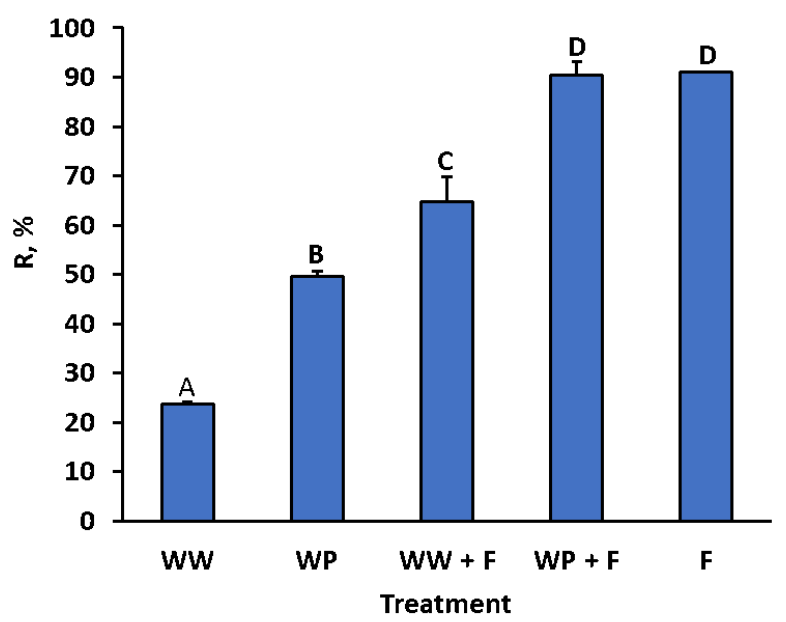

Figure 3. $\mathrm{Pb}$ (II) ion removal efficiency of biosorbents in contact with 1000 $\mu \mathrm{g} / \mathrm{mL} \mathrm{Pb}$ (II) for 60 minutes. Means that share at least one similar letter are not significantly different at Tukey's multiple comparisons test $(\mathrm{P}<$ 0.05). Assuming equal variances, Brown-Forsythe test shows that there are no significant differences between standard deviations of all test groups.

\subsection{Fourier Transform Infrared Spec- troscopy}

Possible functional groups of fungal, wood, and woodimmobilized biomass applied in $\mathrm{Pb}(\mathrm{II})$ sorption were assessed through infrared spectroscopy seen in Figure 4. The FTIR spectra shown in Figure 5 depicts plausible $\mathrm{Pb}(\mathrm{II})$ binding sites in comparison to the biomass before and after $\mathrm{Pb}(\mathrm{II})$ treatment.

All sorbents from Figure 4 contain a broad spectral range of 3267.58 to $3338.77 \mathrm{~cm}^{-1}$ indicating the presence of hydroxyl (-OH) and amine (-NH) groups. Bands observed at peaks 2924.38 to $2901.65 \mathrm{~cm}^{-1}$ are characteristics of $-\mathrm{CH}$ stretching, 1743.63 to $1731.59 \mathrm{~cm}^{-1}$ are likely assigned to $\mathrm{C}=\mathrm{O}$ stretching, 1627.03 to $1595.01 \mathrm{~cm}^{-1}$ are possibly related to amine groups, and peaks located at 703.33 to 663.97 $\mathrm{cm}^{-1}$ are assigned to C-S stretching. These frequencies were detected in all samples as shown in Table 1.

The comparison of immobilized and non-immobilized wood sorbents before and after $\mathrm{Pb}$ (II) treatment are shown in Tables 2 and 3. An apparent change was observed only in peak $1234 \mathrm{~cm}^{-1}$ (C-C, C-O, C=O stretching) of WP, which shifted into $1157.52 \mathrm{~cm}^{-1}$ (C-O-C antisymmetric bridge stretch) after lead binding (Table 2). For WP+F, apparent changes were only observed in peaks $1639.71 \mathrm{~cm}^{-1}$ (amide) and $778.65 \mathrm{~cm}^{-1}$ (arene), which shifted into $1631.10 \mathrm{~cm}^{-1}$ (amide) and none respectively (Table 4).

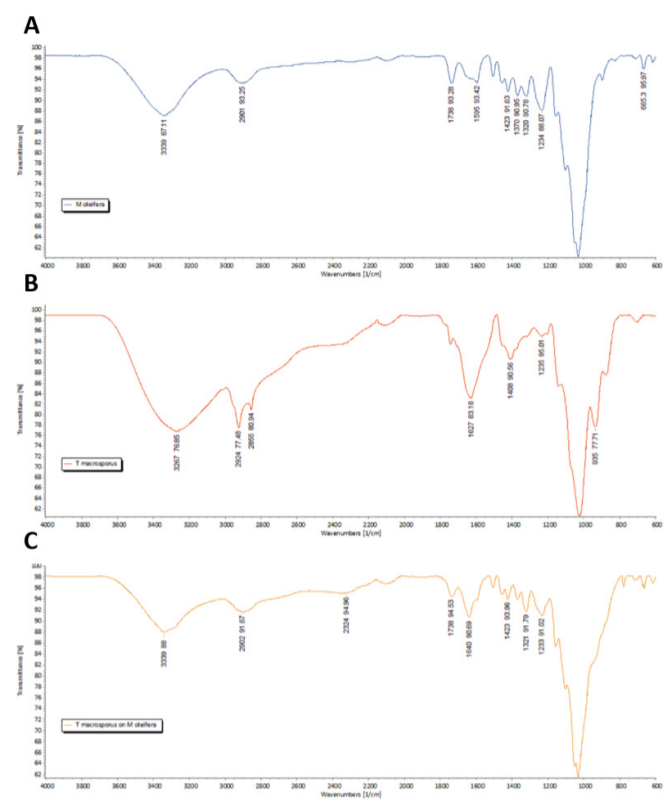

Figure 4. FTIR spectra of sorbents: WP (A) (B) dried fungi (F), and (C) dried wood immobilized with fungi (WP+F).

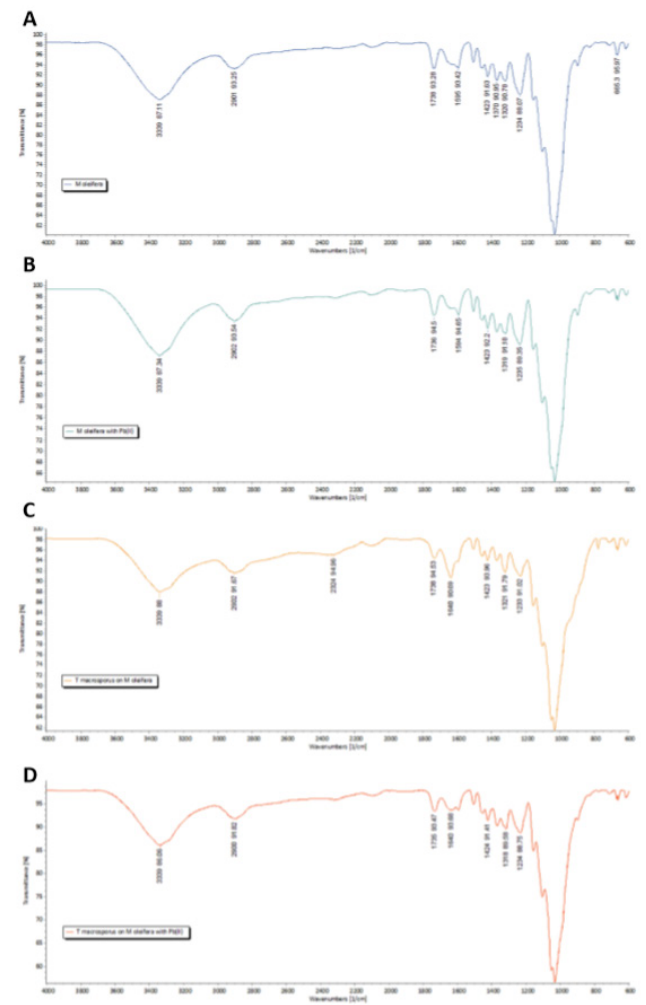

Figure 5. FTIR spectra of WP before (A) and after (B) $\mathrm{Pb}(\mathrm{II})$ treatment, and $\mathrm{WP}+\mathrm{F}$ before $(\mathrm{C})$ and after $(\mathrm{D}) \mathrm{Pb}(\mathrm{II})$ treatment. 
Table 1. List of possible functional groups from fungal, wood, and wood-immobilized biomass involved in $\mathrm{Pb}(\mathrm{II})$ sorption.

\begin{tabular}{|c|c|c|}
\hline Biosorbent & Frequency $\left(\mathrm{cm}^{-1}\right)$ & Functional Group \\
\hline \multirow{8}{*}{ Fungi } & 3267.58 & $-\mathrm{OH}$ and/or $-\mathrm{NH}$ \\
\hline & $2924.38,2854.61$ & -CH stretch (Methylene) \\
\hline & 1743.63 & $\mathrm{C}=\mathrm{O}$ stretch (Alkyl carbonate) \\
\hline & 1627.03 & N-H bend (Amine) \\
\hline & 1408.25 & -C-O stretch \\
\hline & 1235.2 & -C-O stretch (Ether) or $-\mathrm{SO}_{3}$ stretching \\
\hline & 935.22 & P-O-C stretch (Aromatic phosphates) \\
\hline & 703.33 & C-S stretch (disulfide) \\
\hline \multirow{10}{*}{ Wood } & 3339.47 & -OH stretching (Alcohol) \\
\hline & 2902.16 & -CH stretching (Methyl or methylene) \\
\hline & 1737.52 & $\mathrm{C}=\mathrm{O}$ stretching $($ Carboxylic acid $)$ \\
\hline & 1595.01 & $\begin{array}{l}\text { Aromatic ring skeletal vibration } \\
\quad(\mathrm{C}-\mathrm{H}, \mathrm{C}-\mathrm{N}, \text { or } \mathrm{N}-\mathrm{H})\end{array}$ \\
\hline & 1422.75 & $\mathrm{CH}_{3}$ bending or $\mathrm{CH}_{2}$ scissoring \\
\hline & 1370.14 & $\mathrm{CH}$ bending \\
\hline & 1234.16 & $\mathrm{C}-\mathrm{C}, \mathrm{C}-\mathrm{O}$, or $\mathrm{C}=\mathrm{O}$ symmetric stretching \\
\hline & 1104.21 & -OH band \\
\hline & 897.77 & $\mathrm{CH}$ deformation \\
\hline & 665.16 & C-S or S-S stretch (disulfide) \\
\hline \multirow{10}{*}{$\begin{array}{c}\text { Wood } \\
\text { immobilized } \\
\text { with fungi }\end{array}$} & 3338.77 & -OH stretching (Alcohol) \\
\hline & 2901.65 & -CH stretching (Methyl or methylene) \\
\hline & 1731.59 & $\mathrm{C}=\mathrm{O}$ stretching $($ Carboxylic acid $)$ \\
\hline & 1639.71 & $\mathrm{C}=\mathrm{O}$ and $\mathrm{C}-\mathrm{N}-\mathrm{H}$ stretching (Amide) \\
\hline & 1423.46 & $\mathrm{CH}_{3}$ bending or $\mathrm{CH}_{2}$ scissoring \\
\hline & 1370.49 & $\mathrm{CH}$ bending \\
\hline & 1233.01 & $\begin{array}{c}\mathrm{C}-\mathrm{C}, \mathrm{C}-\mathrm{O} \text {, or } \mathrm{C}=\mathrm{O} \text { symmetric stretching } \\
\text { (aromatic phosphate) }\end{array}$ \\
\hline & 1157.47 & $\mathrm{C}-\mathrm{O}-\mathrm{C}$ antisymmetric stretching \\
\hline & 778.65 & Aromatic $\mathrm{C}-\mathrm{H}$ bend \\
\hline & 663.97 & C-S or S-S stretch (disulfide) \\
\hline
\end{tabular}

Changes in the frequencies of the wood before and after fungal immobilization are presented in Table 4. Comparison of the sorbents from Table 1 showed greater similarity in the type of functional groups between $\mathrm{WP}$ and $\mathrm{WP}+\mathrm{F}$ than $\mathrm{F}$ and WP+F. Shifts in carboxylic acid (1737.52 to 1731.59 $\left.\mathrm{cm}^{-1}\right)$, C-O-C (1104.21 to $\left.1157.47 \mathrm{~cm}^{-1}\right)$, and aromatic $\mathrm{CH}$ (897.77 to $778.65 \mathrm{~cm}^{-1}$ ) groups were observed between WP and $\mathrm{WP}+\mathrm{F}$ sorbents. A major change also appeared in the band shift of 1595.01 to $1639.71 \mathrm{~cm}^{-1}$ suggesting a previous aromatic ring modification to an amino or carbonyl group.

\subsection{CF Test}

Following the results of the contact test, the residual $\mathrm{Pb}(\mathrm{II})$ ion concentration, removal efficiency, and biosorption capacity of WP versus $\mathrm{WP}+\mathrm{F}$ in 1000,2000 , and $4000 \mu \mathrm{g} / \mathrm{mL}$ $\mathrm{Pb}$ (II) concentrations were tested using a CF column setup (Figure 6, 7 and 8)

Residual lead ion $\mathrm{Pb}(\mathrm{II})$ for $\mathrm{WP}$ and $\mathrm{WP}+\mathrm{F}$ for all concentrations is summarized in Figure 6 with $\mathrm{WP}+\mathrm{F}$ treatment having significantly lower $(\mathrm{P}<0.05)$ residual $\mathrm{Pb}$ (II) concentrations than WP signifying a higher $\mathrm{Pb}(\mathrm{II})$ uptake than WP at 93, 167, and $183 \mu \mathrm{g} / \mathrm{mL}$ for 1000 , 2000, and $4000 \mu \mathrm{g} / \mathrm{mL}$ respectively. WP residual $\mathrm{Pb}$ (II) concentration resulted to more than twice the value as the concentration also doubly increased from 1000 to 2000 $\mu \mathrm{g} / \mathrm{mL}$ with 453 to $1323 \mu \mathrm{g} / \mathrm{mL} \mathrm{Pb}(\mathrm{II})$ that remained and 2000 to 4000 with 1323 to $3380 \mu \mathrm{g} / \mathrm{mL}$ residual ions left in the solution (Figure 6E). A decreasing trend of
Table 2. Comparison of FTIR spectra between wood (WP) before and after $\mathrm{Pb}(\mathrm{II})$ sorption.

\begin{tabular}{|c|c|c|c|}
\hline Before & After & Functional Group & Possible Assignments \\
\hline 3339.47 & 3338.63 & $\begin{array}{l}\text {-OH stretching } \\
\text { (Alcohol) }\end{array}$ & $\begin{array}{c}\text { Cellulose } \\
\text { (Naumann, 2015) }\end{array}$ \\
\hline 2902.16 & 2901.16 & $\begin{array}{l}\text {-CH stretching } \\
\text { (Methyl or } \\
\text { methylene) }\end{array}$ & $\begin{array}{c}\text { Cellulose (Mohaček-Gro } \\
\text { šev et al. 2001) }\end{array}$ \\
\hline 1737.52 & 1735.9 & $\begin{array}{c}\mathrm{C}=\mathrm{O} \text { stretching } \\
\text { (carboxylic acid) }\end{array}$ & $\begin{array}{l}\text { Xylans, hemicellulose } \\
\text { (Traore } \text { et al., 2017, } \\
\text { Fahey et al. 2017) }\end{array}$ \\
\hline 1595.01 & 1593.67 & $\begin{array}{l}\text { Aromatic ring } \\
\text { skeletal vibration }\end{array}$ & Lignin (Faix 1991) \\
\hline 1422.75 & 1423.09 & $\begin{array}{l}\mathrm{CH}_{3} \text { bending or } \mathrm{CH}_{2} \\
\text { scissoring }\end{array}$ & $\begin{array}{l}\text { Lignin and cellulose } \\
\text { (Traore } \text { et al. 2017, } \\
\text { Fahey et al. 2017, Faix } \\
\text { 1991) }\end{array}$ \\
\hline 1370.14 & 1370.02 & $\mathrm{CH}$ bending & $\begin{array}{l}\text { Polysaccharides (Liang } \\
\text { \& Marchessault 1959) }\end{array}$ \\
\hline 1319.55 & 1319.07 & $\mathrm{CH}_{2}$ wagging & $\begin{array}{c}\text { Cellulose (Liang \& } \\
\text { Marchessault, 1959) }\end{array}$ \\
\hline 1234.16 & 1157.52 & $\begin{array}{l}\text { From C-C, C-O, or } \\
\mathrm{C}=\mathrm{O} \text { symmetric } \\
\text { stretching to } \mathrm{C}-\mathrm{O}-\mathrm{C} \\
\text { antisymmetric } \\
\text { stretching (Ether) }\end{array}$ & $\begin{array}{l}\text { Lignin (Fahey et al. } \\
\text { 2017, Liang \& } \\
\text { Marchessault, 1959) }\end{array}$ \\
\hline 1104.21 & 1104.55 & $-\mathrm{OH}$ band & $\begin{array}{c}\text { Polysaccharides (Higgins } \\
\text { et al. 1961) }\end{array}$ \\
\hline 1032.09 & 1031.96 & C-O stretching & $\begin{array}{l}\text { Lignin, primary and } \\
\text { secondary alcohols in } \\
\text { cellulose, and } \\
\text { polysaccharides } \\
\text { (Traore } \text { et al. } 2017 \text { ) }\end{array}$ \\
\hline 897.77 & 897.76 & $\mathrm{CH}$ deformation & $\begin{array}{l}\text { Beta-glycosidic bonds in } \\
\text { cellulose } \\
\text { (Evans } \text { et al. 1992) }\end{array}$ \\
\hline 665.16 & 663.76 & $\begin{array}{l}\text { C-S stretch } \\
\text { or S-S stretch } \\
\text { (disulfide) }\end{array}$ & $\begin{array}{l}\text { Disulfide bridges } \\
\text { (cysteine) from common } \\
\text { plant cell wall proteins } \\
\text { (Galgoczy et al. } 2019 \text { ) }\end{array}$ \\
\hline
\end{tabular}

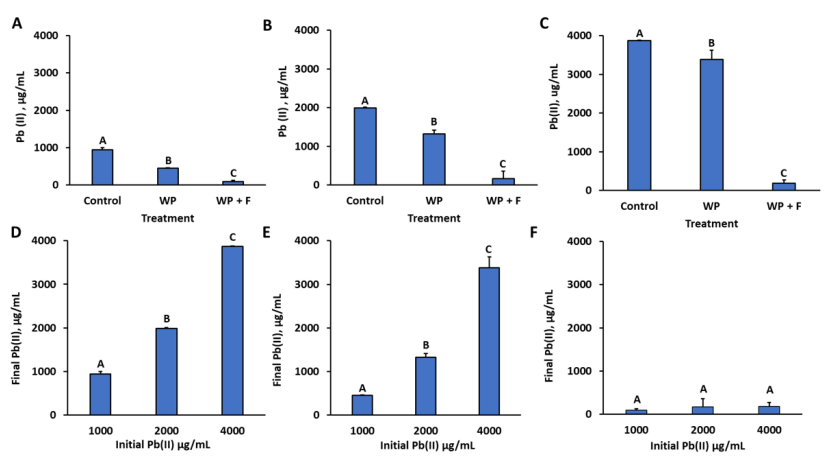

Figure 6. Residual $\mathrm{Pb}(\mathrm{II})$ ion concentration of biosorbents (WP, WP+F) in contact with 1000 (A), 2000 (B), and $4000 \mu \mathrm{g} / \mathrm{mL} \mathrm{Pb(II)} \mathrm{(C)} \mathrm{for} 30$ minutes in assembled $\mathrm{CF}$ system. Comparison of residual $\mathrm{Pb}$ (II) ion concentration of control (D), WP (E), and WP+F (F) in 1000, 2000, and $4000 \mu \mathrm{g} / \mathrm{mL}$ $\mathrm{Pb}$ (II) concentrations. Means that share at least one similar letter are not significantly different at Tukey's multiple comparisons test $(\mathrm{P}<0.05)$. Bars indicate standard deviation of at least three replicates. 
Table 3. Comparison of FTIR spectra between wood immobilized with fungi $(\mathrm{WP}+\mathrm{F})$ before and after $\mathrm{Pb}$ (II) sorption.

\begin{tabular}{|c|c|c|c|}
\hline Before & After & Functional Group & Possible Assignments \\
\hline 3338.77 & 3338.79 & $\begin{array}{l}\text {-OH stretching } \\
\text { (Alcohol) }\end{array}$ & $\begin{array}{l}\text { Cellulose (plant) or chitin } \\
\text { (fungi) (Naumann, 2015) }\end{array}$ \\
\hline 2901.65 & 2901.64 & $\begin{array}{l}\text {-CH stretching } \\
\text { (Methyl } \\
\text { or methylene) }\end{array}$ & $\begin{array}{l}\text { Cellulose (plant) or chitin } \\
\text { (fungi) (Naumann, 2015) }\end{array}$ \\
\hline 1731.59 & 1734.84 & $\begin{array}{l}\mathrm{C}=\mathrm{O} \text { stretching } \\
\text { (carboxylic acid) }\end{array}$ & $\begin{array}{l}\text { Xylans, hemicellulose, } \\
\text { mannan (Naumann, 2015) }\end{array}$ \\
\hline 1639.71 & 1631.1 & $\begin{array}{l}\mathrm{C}=\mathrm{O} \text { and } \mathrm{C}-\mathrm{N}-\mathrm{H} \\
\text { stretching (amide) }\end{array}$ & $\begin{array}{c}\text { Chitin amide } \\
\text { (Naumann, 2015) }\end{array}$ \\
\hline 1423.46 & 1423.63 & $\begin{array}{l}\mathrm{CH}_{3} \text { bending or } \\
\mathrm{CH}_{2} \text { scissoring }\end{array}$ & $\begin{array}{l}\text { Lignin and cellulose } \\
\text { (Naumann, 2015) }\end{array}$ \\
\hline 1370.49 & 1369.91 & CH bending & $\begin{array}{l}\text { Polysaccharides } \\
\text { (Naumann, 2015) }\end{array}$ \\
\hline 1233.01 & 1234.02 & $\begin{array}{l}\mathrm{C}-\mathrm{C}, \mathrm{C}-\mathrm{O} \text {, or } \mathrm{C}=\mathrm{O} \\
\text { symmetric } \\
\text { stretching }\end{array}$ & Lignin (Fahey et al. 2017) \\
\hline 1157.47 & 1158.29 & $\begin{array}{c}\text { C-O-C } \\
\text { antisymmetric } \\
\text { stretching (ether) }\end{array}$ & $\begin{array}{c}\text { Polysaccharides (Fahey et } \\
\text { al. 2017, Liang \& } \\
\text { Marchessault 1959) }\end{array}$ \\
\hline 778.65 & - & $\begin{array}{l}\text { From aromatic } \mathrm{CH} \\
\text { bend to apparent } \\
\text { loss of functionality }\end{array}$ & $\begin{array}{l}\text { Lignin fragments } \\
\text { (guaiacyl) and beta- } \\
\text { galactosyl residues } \\
\text { (Fahey et al. } 2017 \text { ) }\end{array}$ \\
\hline 663.97 & 663.61 & $\begin{array}{l}\text { C-S stretch or S-S } \\
\text { stretch (disulfide) }\end{array}$ & $\begin{array}{c}\text { Disulfide bridges } \\
\text { (Galgoczy et al. } 2019)\end{array}$ \\
\hline
\end{tabular}

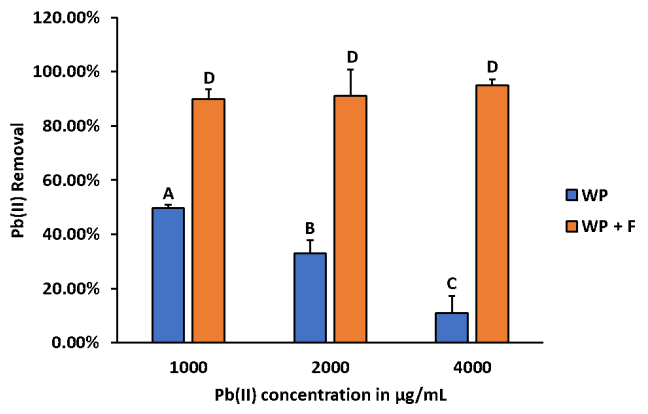

Figure 7. $\mathrm{Pb}(\mathrm{II})$ ion removal efficiency (\%) of biosorbents (WP, WP+F) in contact with 1000,2000 , and $4000 \mu \mathrm{g} / \mathrm{mL}$ Pb(II) for 30 minutes in assembled $\mathrm{CF}$ system. Means that share at least one similar letter are not significantly different at Tukey's multiple comparisons test $(\mathrm{P}<0.05)$. Bars indicate standard deviation of at least three replicates.
Table 4. Comparison of FTIR spectra between wood (WP) before and after fungal colonization $(\mathrm{WP}+\mathrm{F})$.

\begin{tabular}{|c|c|c|c|}
\hline Before & After & Functional Group & Possible Assignments \\
\hline 3339.47 & 3338.77 & $\begin{array}{l}-\mathrm{OH} \text { stretching } \\
\text { (Alcohol) }\end{array}$ & $\begin{array}{l}\text { Cellulose (plant) or } \\
\text { chitin (fungi) } \\
\text { (Naumann, 2015) }\end{array}$ \\
\hline 2902.16 & 2901.65 & $\begin{array}{l}\text {-CH stretching } \\
\text { (Methyl or } \\
\text { methylene) }\end{array}$ & $\begin{array}{l}\text { Cellulose (plant) or } \\
\text { chitin (fungi) } \\
\text { (Naumann, 2015) }\end{array}$ \\
\hline 1737.52 & 1731.59 & $\begin{array}{l}\mathrm{C}=\mathrm{O} \text { stretching } \\
\text { (carboxylic acid) }\end{array}$ & $\begin{array}{c}\text { Xylans, hemicellulose, } \\
\text { mannan } \\
\text { (Naumann, 2015) }\end{array}$ \\
\hline 1595.01 & 1639.71 & $\begin{array}{c}\text { From aromatic ring } \\
\text { skeletal vibration } \\
\text { (lignols) to } \mathrm{C}=\mathrm{O} \text { and } \\
\mathrm{C}-\mathrm{N}-\mathrm{H} \text { stretching } \\
\text { (amide) }\end{array}$ & $\begin{array}{c}\text { Chitin amide } \\
\text { (Naumann, 2015) }\end{array}$ \\
\hline 1422.75 & 1423.46 & $\begin{array}{c}\mathrm{CH}_{3} \text { bending or } \mathrm{CH}_{2} \\
\text { scissoring }\end{array}$ & $\begin{array}{l}\text { Lignin and cellulose } \\
\text { (Traore } \text { et al. 2018, } \\
\text { Naumann, 2015) }\end{array}$ \\
\hline 1370.14 & 1370.49 & $\mathrm{CH}$ bending & $\begin{array}{l}\text { Polysaccharides (Liang } \\
\& \text { Marchessault 1959) }\end{array}$ \\
\hline 1234.16 & 1233.01 & $\begin{array}{c}\mathrm{C}-\mathrm{C}, \mathrm{C}-\mathrm{O} \text {, or } \mathrm{C}=\mathrm{O} \\
\text { symmetric stretching }\end{array}$ & $\begin{array}{c}\text { Lignin (Liang \& } \\
\text { Marchessault, 1959) }\end{array}$ \\
\hline 1104.21 & 1157.47 & $\begin{array}{c}\text { C-O-C } \\
\text { antisymmetric } \\
\text { stretching (Ether) }\end{array}$ & $\begin{array}{l}\text { Polysaccharides (Fahey } \\
\text { et al. 2017, Liang \& } \\
\text { Marchessault, 1959) }\end{array}$ \\
\hline 897.77 & 778.65 & Aromatic $\mathrm{CH}$ bend & $\begin{array}{l}\text { Lignin fragments } \\
\text { (guaiacyl) and beta- } \\
\text { galactosyl residues } \\
\text { (Fahey et al. 2017) }\end{array}$ \\
\hline 665.16 & 663.97 & $\begin{array}{l}\text { C-S stretch or S-S } \\
\text { stretch (disulfide) }\end{array}$ & $\begin{array}{c}\text { Disulfide bridges } \\
\text { (Galgoczy et al. } 2019)\end{array}$ \\
\hline
\end{tabular}

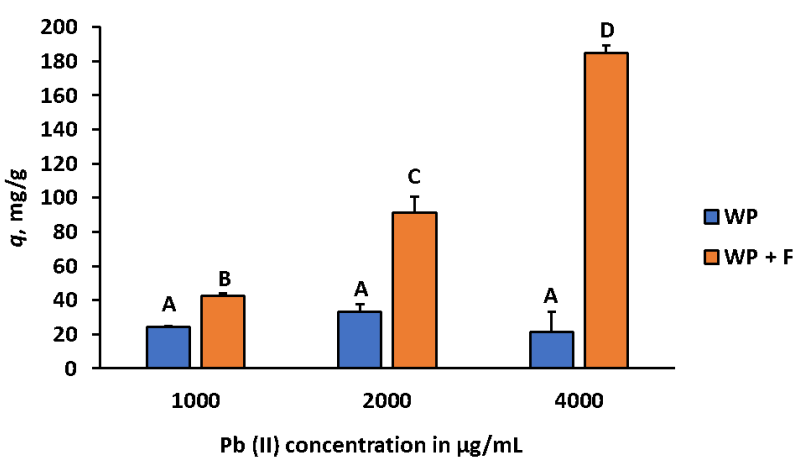

Figure 8. Biosorption capacity $(q)$ of biosorbents (WP, WP+F) in contact with 1000,2000 , and $4000 \mu \mathrm{g} / \mathrm{mL} \mathrm{Pb}$ (II) for 30 minutes in assembled CF system. Two-way ANOVA shows that means are statistically significantly different at $\mathrm{P}<0.05$. Means that share at least one similar letter are not significantly different at Tukey's multiple comparisons test $(P<0.05)$. Bars indicate standard deviation of at least three replicates. 
the removal efficiency of WP tested in increasing $\mathrm{Pb}(\mathrm{II})$ concentrations presented in Figure 7 is congruent to these results. However, the residual ion concentration of $\mathrm{WP}+\mathrm{F}$ is not significantly different at different $\mathrm{Pb}(\mathrm{II})$ concentrations at $\mathrm{P}<0.05$ (Figure 6F). This is similarly represented in Figure 7, where the removal efficiency of $\mathrm{WP}+\mathrm{F}$ remained statistically insignificant at $90-95 \%$, unaffected by initial $\mathrm{Pb}(\mathrm{II})$ concentration.

The biosorption capacity $(q)$ of $\mathrm{WP}+\mathrm{F}$ significantly increases from 42.67 to 91.13 , and from 92.3 to 184.83 as $\mathrm{Pb}$ (II) concentration increases from $1000 \mathrm{ppm}$ to $2000 \mathrm{ppm}$ and from $2000 \mathrm{ppm}$ to $4000 \mathrm{ppm}$ respectively (Figure 8). The $q$ of $\mathrm{WP}+\mathrm{F}$ was also found to be significantly higher than that of WP at $\mathrm{P}<0.05$, with the latter having an insignificantly different $q$ for the same biosorbent groups regardless of initial $\mathrm{Pb}(\mathrm{II})$ concentration.

A comparison of the residual $\mathrm{Pb}(\mathrm{II})$ concentrations for the contact test and the CF test is shown below in Figure 9. There are no significant differences between the contact test and $\mathrm{CF}$ results at $\mathrm{P}<0.05$ for $\mathrm{WP}$ and $\mathrm{WP}+\mathrm{F}$.

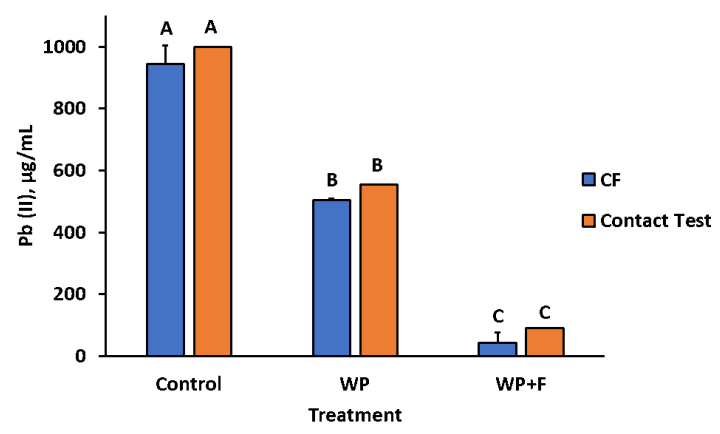

Figure 9. Comparison of Contact test and $\mathrm{CF}$ residual $\mathrm{Pb}$ (II) ion concentration by biosorbents in contact with $1000 \mu \mathrm{g} / \mathrm{mL} \mathrm{Pb}$ (II). Means that share at least one similar letter are not significantly different at Tukey's multiple comparisons test $(\mathrm{P}<0.05)$. Assuming equal variances, Sidak's multiple comparisons test shows that there are no significant differences between computed (Contact Test) and actual values (CF) of all test groups.

T. macrosporus immobilized in wood was shown to yield an average of $0.16 \pm 0.016$ grams from Table 5. Furthermore, preparation of the powdered wood-fungal biosorbent did not exhibit fungal growth after 4 days of incubation from Figure 10 .

\section{5 $\mathrm{Pb}(\mathrm{II})$ Desorption from WP+F Biosorbent}

Amounts of $\mathrm{Pb}(\mathrm{II})$ desorbed and recovery percentage of the powdered wood-fungal biosorbent $(\mathrm{WP}+\mathrm{F})$ are shown in Figures 11 and 12.

Desorption of the $\mathrm{Pb}(\mathrm{II})$ ions from $\mathrm{WP}+\mathrm{F}$ biomass in contact with all concentrations was not significantly different
Table 5. Fungal weight in immobilized biosorbent in grams (g). The average weight increase by fungal colonization was $0.16 \pm 0.016$.

\begin{tabular}{ccc}
\hline $\begin{array}{c}\text { Dried Wood } \\
(\mathbf{W W})(\mathbf{g})\end{array}$ & $\begin{array}{c}\text { Dried Colonized } \\
(\mathbf{W W}+\mathbf{F})(\mathbf{g})\end{array}$ & $\begin{array}{c}\text { Fungal Weight } \\
(\mathbf{g})\end{array}$ \\
\hline $1.20 \pm 0.002$ & $1.40 \pm 0.010$ & $0.20 \pm 0.010$ \\
$1.25 \pm 0.002$ & $1.42 \pm 0.009$ & $0.17 \pm 0.020$ \\
$1.25 \pm 0.003$ & $1.43 \pm 0.010$ & $0.18 \pm 0.020$ \\
$0.94 \pm 0.010$ & $1.04 \pm 0.021$ & $0.10 \pm 0.020$ \\
$0.91 \pm 0.012$ & $1.05 \pm 0.022$ & $0.14 \pm 0.010$ \\
\hline
\end{tabular}

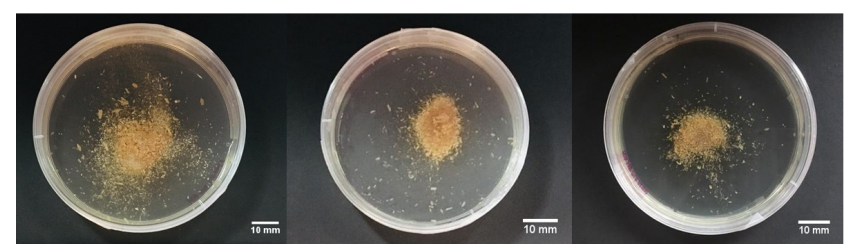

Figure 10. Triplicate viability test of $\mathrm{WP}+\mathrm{F}$ tested on PDA plates supplemented with $50 \mu \mathrm{g} / \mathrm{mL}$ amp. Photographs were taken after 5 days of incubation at $30^{\circ} \mathrm{C}$.

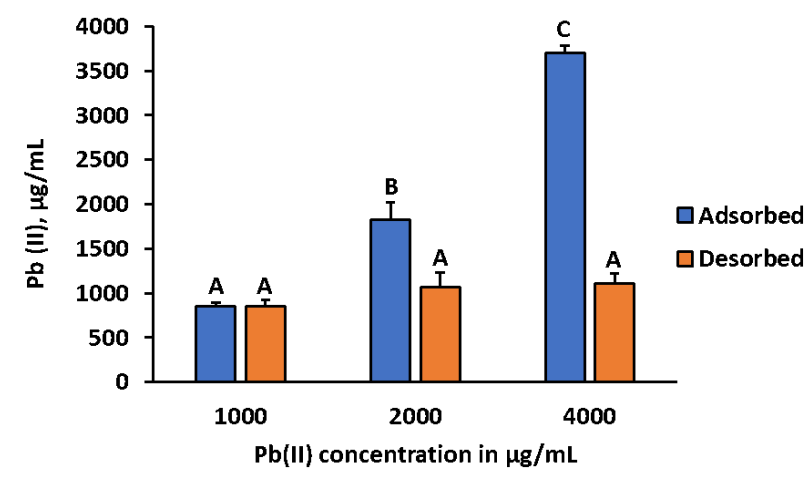

Figure 11. Comparison of adsorbed and desorbed $\mathrm{Pb}$ (II) ions of utilized $\mathrm{WP}+\mathrm{F}$ biosorbents in CF test for concentrations of 1000, 2000, and 4000 $\mu \mathrm{g} / \mathrm{mL}$. Two-way ANOVA shows that means are statistically significantly different at $\mathrm{P}<0.05$. Means that share at least one similar letter are not significantly different at Tukey's multiple comparisons test $(\mathrm{P}<0.05)$. Bars indicate standard deviation of at least three replicates.
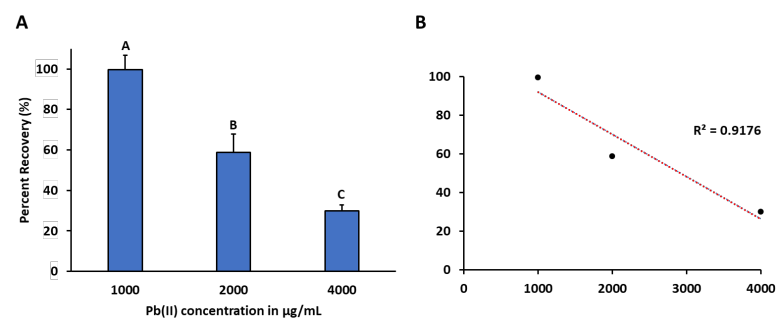

Figure 12. Percent recovery $(\%)$ of $\mathrm{WP}+\mathrm{F}$ biosorbents from $\mathrm{CF}$ set-up in contact with 1000,2000 , and $4000 \mu \mathrm{g} / \mathrm{mL} \mathrm{Pb}$ (II) solutions after treatment with $1.0 \mathrm{M} \mathrm{HCl}$ for 60 minutes. One-way ANOVA shows that means are statistically significantly different at $\mathrm{P}<0.05$. Bars indicate standard deviation of at least three replicates (A). A linear regression model produced an $\mathrm{R}^{2}$ value of 0.9176 to express the relationship between the data points (B). 
$(\mathrm{P}<0.05)$ from the $\mathrm{Pb}(\mathrm{II})$ ions adsorbed at $1000 \mu \mathrm{g} / \mathrm{mL}$ as presented in Figure 11. However, it is important to note that most of the $\mathrm{Pb}$ (II) ions adsorbed by the biomass at 1000 $\mu \mathrm{g} / \mathrm{mL}$ were recovered at $99.61 \%$ shown in Figure 12 . From the same figure, an almost linear decrease of the recovery percentage was shown as the $\mathrm{Pb}$ (II) ion concentration doubles from $99.61 \%$ to $58.71 \%$ for 1000 to $2000 \mu \mathrm{g} / \mathrm{mL}$ and $58 \%$ to $30.02 \%$ for 2000 to $4000 \mu \mathrm{g} / \mathrm{mL}$. This trend is supported by the regression model which produced an $\mathrm{R}^{2}$ value of 0.9176 indicating a large positive linear association.

\section{Discussion}

\subsection{Preparation of Wood-immobilized Fungal Biosorbent and SEM Analysis}

Fungal colonization of the prepared biosorbent produced similar results to the study using Carica papaya softwood (Iqbal and Saeed, 2006). The growth of T. macrosporus mycelia along the surface of $M$. oleifera wood as shown in Figure $1 \mathrm{C}$ presented a uniform distribution. This allows for a greater number of open binding sites, and exposure of a wider surface area for HM binding (Ding et al., 2019). This represents one of the advantages of immobilized systems over free cell suspension cultures where the latter is tightly clumped resulting in diffusional restrictions and lower surface area of adsorption (Ramrakhiani et al., 2016; Iqbal and Edyvean, 2004).

The entrapment of T. macrosporus mycelia on M. oleifera wood in a relatively short time span of seven days indicates the efficiency in generating the biosorbent without prior chemical treatment. This is in contrast with several other modes of immobilization that are costly, laborious, and require sophisticated equipment (Iqbal and Saeed, 2006). This also addresses common operative obstacles found in the preparation of most immobilizing materials such as their poor mechanical strength, restrictive diffusion capacities, and lack of open spaces to accommodate active cell growth (Sriharsha et al., 2017; Li et al., 2008).

\subsection{Initial CT}

The $\mathrm{Pb}(\mathrm{II})$ removal efficiency of $T$. macrosporus is highlighted in Figure 3 where the removal percentage of $\mathrm{F}$ (91.02\%), WW+F (64.81\%), and WP+F (90.37\%) are significantly higher than that of WW $(23.70 \%)$ and WP $(49.63 \%)$. These findings are in line with studies wherein immobilants colonized with fungi removed more heavy metals in solution than the immobilant alone (Sriharsha et al., 2017; Zahmatkesh et al., 2018; Iqbal and Saeed, 2006). This may be due to the sheer number of complex fungal polysaccharide residues such as chitin and glucan, which are found to be more abundant in available binding sites compared to other plant polysaccharides such as cellulose and lignin (Ge and Li, 2018; Shakya et al., 2016).

However, the $\mathrm{Pb}(\mathrm{II})$ removal efficiency between $\mathrm{F}$ and $\mathrm{WP}+\mathrm{F}$ were not significantly different from each other despite the lower fungal biomass component of $\mathrm{WP}+\mathrm{F}(0.16$ $\pm 0.016 \mathrm{~g})$ compared to $\mathrm{F}(1.20 \pm 0.006 \mathrm{~g})$ as seen in Table 5 . This finding differs from the studies of Ding et al. (2019), Sriharsha et al. (2017), Ramrakhiani et al. (2016), and Iqbal \& Saeed (2006) wherein their immobilized system biosorbents had a significantly higher removal efficiency than fungi alone. This may indicate an inherent strength of polarity and abundance of effective binding sites found on the fungal cell wall even at low amounts of fungal biomass (Ge and Li, 2018).

Aside from functional group abundance and availability, it has also been suggested that fungal colonization of wood has biochemical impacts on the structure of plant cell walls, enhancing HM binding capacity (Saravanan and Ravikumar, 2015). Certain Ascomycete enzymes such as lignin peroxidase, hemicellulase, laccase, phenol oxidase, cellobiose dehydrogenase, beta-glucosidase, and cellulase (Janusz et al., 2017; Goyari et al., 2015), can cleave the covalent linkages between lignin, cellulose, hemicellulose, pectin, and other polysaccharide components of lignocellulose, increasing the number, distribution, exposure, and polarity of metalaffinitive functional groups in wood tissue (Zhao et al., 2018).

\subsection{FTIR Analysis}

The FTIR spectra of dried fungal biomass, wood immobilized, and non-immobilized sorbents from Figure 4 were analyzed to list and verify possible sorbent-metal ion binding sites in $\mathrm{Pb}$ (II) removal. FTIR has previously been used to identify potential sorption sites for $\mathrm{Pb}$ (II) in fungal biomass (Aytar et al., 2014), various wood and cellulosic tissues (Traoré et al., 2017; Fahey et al., 2017; Malik et al., 2016), and wood derived materials (Putra et al., 2014).

Dried fungal biomass has been documented to possess hydroxyl, amino, and carboxyl groups from $\mathrm{N}$ acetylglucosamine as components of their chitinous cell walls which have been proven to bind to $\mathrm{Pb}$ (II) ions (Long et al., 2019; Sriharsha et al., 2017; Gube, 2016). Similarly, sulfhydryl (Akar et al., 2007) and carbonyl groups (Aytar et al., 2014) have been also documented in $\mathrm{Pb}$ (II) binding. Results from Table 1 confirm the presence of several functional groups common to other Ascomycetes capable of $\mathrm{Pb}$ (II) sorption (Long et al., 2019).

Similar to fungal biomass, the use of cellulosic materials in the removal of various heavy metals including $\mathrm{Pb}$ (II) has been described and summarized extensively (Malik et al., 2016). Cellulosic, hemicellulosic, and lignin components from wood sorbents may contain hydroxyl, amino, aromatic, and carbonyl groups responsible for HM binding (Putra et al., 2014). These components were detected in WW, WP, 
$\mathrm{WW}+\mathrm{F}$, and $\mathrm{WP}+\mathrm{F}$, presented in Table 1.

Comparing the IR spectra of the sorbents before and after $\mathrm{Pb}(\mathrm{II})$ exposure shown in Tables 2 and Table 3 indicate minimal peak shifts within -OH (3339.47 to $\left.3338.63 \mathrm{~cm}^{-1}\right)$, CH (2902.16 to $\left.2901.16 \mathrm{~cm}^{-1}\right)$, and C-S and S-S (665.16 to $\left.663.76 \mathrm{~cm}^{-1}\right)$, and a major change in the vibration band intensities of the binding sites at 1234.15 to $1157.52 \mathrm{~cm}^{-1}$ (from $\mathrm{C}=\mathrm{O}$ to $\mathrm{C}-\mathrm{O}-\mathrm{C}$ ) for $\mathrm{WP}$, and 1639.71 to $1631.10 \mathrm{~cm}^{-1}$ $(\mathrm{C}=\mathrm{O}$ and $\mathrm{C}-\mathrm{N}-\mathrm{H})$ and $778.65 \mathrm{~cm}^{-1}$ to none (aromatic $\mathrm{CH}$ ) for $\mathrm{WP}+\mathrm{F}$.

The shift of the peak intensity from 1234.15 to 1157.52 $\mathrm{cm}^{-1}$ in WP (Table 2) may indicate binding of $\mathrm{Pb}$ (II) to $\mathrm{C}=\mathrm{O}$ groups in lignin which forms a more stable complex leading to a lower $\mathrm{C}=\mathrm{O}$ peak intensity; this may also refer to the exposure of more $\mathrm{C}-\mathrm{O}-\mathrm{C}$ groups that constitute other lignin components and glycosidic linkages (Njoki et al., 2016). For $\mathrm{WP}+\mathrm{F}$ (Table 3), the shift of the peak intensity from 1639.71 to $1631.10 \mathrm{~cm}^{-1}$ may indicate binding of $\mathrm{Pb}(\mathrm{II})$ towards the electronegative oxygen or nitrogen group, while the loss of peak intensity from $778.65 \mathrm{~cm}^{-1}$ may indicate $\mathrm{Pb}$ (II) capture by arenes which form less reactive organometallic complexes (Yang et al., 2018). Minimal and apparent shifts in peak intensities observed in both WP and $\mathrm{WP}+\mathrm{F}$ after $\mathrm{Pb}$ (II) sorption (Table 2, 3) confirm the possible involvement of hydroxyl, carboxyl, amine, and aromatic groups in the adsorption process following $\mathrm{Pb}(\mathrm{II})$ exposure as described in literature (Aytar et al., 2014).

Furthermore, apparent shifts in peak intensities can be observed within 1595.01 to $1639.71 \mathrm{~cm}^{-1}$ (lignol to amide), 1104.21 to $1157.47 \mathrm{~cm}^{-1}$ (ether), and 897.77 to $778.65(\mathrm{CH}$ deformation into arene) in wood after fungal colonization (Table 4). These suggest chemical changes or rearrangements in the plant cell wall components following fungal enzymatic attack (Cui et al., 2017). For instance, the peak shift from 1595.01 to $1639.71 \mathrm{~cm}^{-1}$ (lignol to amide) may be due to the cross-linking of fungal cell wall proteins with galactosyl residues on lignin thereby forming a chitin amide (Naumann et al., 2005). The peak shift from 897.77 to 778.65 $\mathrm{cm}^{-1}$ (CH deformation into arenes) which, following Fahey et al. (2017), is assigned to the formation of beta galactosyl residues and lignol units, indicating cleavage of lignocellulose into simpler chemical units by fungal interaction (Chen et al., 2011).These suggested chemical changes on the plant cell wall by fungal interaction may have affected biosorption capacity and $\mathrm{Pb}(\mathrm{II})$ removal by the $\mathrm{WP}+\mathrm{F}$ biosorbent, another possible explanation as to why $\mathrm{WP}+\mathrm{F}$ has no significant difference in biosorption capacity compared to $\mathrm{F}$, but has significantly more $\mathrm{Pb}$ (II) sorption compared to $\mathrm{WW}$ and $\mathrm{WP}$ at $\mathrm{P}<0.05$.

\subsection{CF Tests}

Following the results of the $\mathrm{Pb}$ (II) contact test, the $\mathrm{Pb}$ (II) biosorption capacities $(q)$ of $\mathrm{WP}$ and $\mathrm{WP}+\mathrm{F}$ in a $\mathrm{CF}$ setup were investigated. The sorption of $\mathrm{WP}+\mathrm{F} \mathrm{Pb}(\mathrm{II})$ was found to be higher compared to WP (Figures 6-8), with $q$ values for $\mathrm{WP}+\mathrm{F}$ growing concomitant to increasing $\mathrm{Pb}$ (II) concentrations (Figure 8) similar to the work of Long et al. (2019), Akar et al. (2005), and Say et al. (2003a,b). This may be primarily attributed to the inherently high amounts of chitin and other heavily glycosylated substances found on the fungal cell wall which are widely documented for their functionality in stable, high-capacity $\mathrm{Pb}$ (II) binding and complexation (Ayangbenro and Babalola, 2017; Dhankhar and Hooda, 2011). These binding site characteristics coupled with elevated metal concentrations favors high mass transfer which drives sorbent-metal collisions that ultimately increase sorption (Fan et al., 2008).

On the other hand, $q$ values for WP which have no significant differences $(\mathrm{P}>0.05)$ despite increasing initial $\mathrm{Pb}(\mathrm{II})$ concentrations (Figure 8). This may indicate a limitation in the number and/or distribution of $\mathrm{Pb}$ (II)-affinitive sites for WP. This is not surprising since plant cellulose and lignocellulose, while having HM-binding sites, have been reported to have poor application for metal adsorption due to their tightly closed crystalline chemical structure that decreases the number and availability of exposed HM-binding sites (Morin-Crini et al., 2018).

Despite the lower $q$ values for WP, values ranging from 21.17 - $33.33 \mathrm{mg} / \mathrm{g}$ are still higher than most other $M$. oleifera components tested in $\mathrm{Pb}$ (II) biosorption studies, such as the bark, fruit, leaf and seed (Basra et al., 2014; Obuseng et al., 2012; Reddy et al., 2010; Mataka et al., 2006). The differences in the ratios of lignin, cellulose, and hemicellulose on the cell wall of different plant tissues can influence the density, polarity, number, and distribution of metal-affinitive functional groups such as hydroxyl, carbonyl, and sulfhydryl (Chen et al., 2011). Both sapwood and heartwood generally have a higher overall lignin-cellulose-hemicellulose ratio than leaves, roots, or bark which may explain the greater sorption capacities for $M$. oleifera softwood measured in this work (Morin-Crini et al., 2018; Jin et al., 2012).

Comparing $q$ values between the $\mathrm{CF}$ test and the immobilant-free CT at $1000 \mu \mathrm{g} / \mathrm{mL}$ (Figure 9), it can be seen that there was no significant difference between the treatments $(\mathrm{P}<0.05)$, indicating that application of the biosorbent in a spatially different setup such as a column filtration system does not significantly change its ability to remediate $\mathrm{Pb}(\mathrm{II})$ at $1000 \mu \mathrm{g} / \mathrm{mL}$. This suggests that the biosorbent is stable for use in a column system with continuous flow of contaminated wastewater at the parameters tested in this work, making it ideal for industrial application. Moreover, the preparation as a non-living biomass (Figure 10) confers usage advantages such as its inability to change fungal cell surface structures and/or secrete extrolites which can affect its efficacy as a biosorbent over time. The WP+F set up shows no further growth after 
drying, an important consideration for its application and use.

\section{5 $\mathrm{Pb}(\mathrm{II})$ Desorption from WP+F Biosorbent}

To verify the $\mathrm{Pb}$ (II) ions adsorbed by the biomass in the assembled CF set-up and determine its potential reusability in $\mathrm{Pb}(\mathrm{II})$ ion recycling processes after water treatment, the amount of $\mathrm{Pb}(\mathrm{II})$ ions should be readily desorbed under suitable conditions. The recovery of the $\mathrm{Pb}$ (II) ions was not significantly different at $\mathrm{P}<0.05$ regardless of concentrations (Figure 11). However, the highest recovery percentage of $99.61 \%$ from the biosorbent was found in contact with $1000 \mu \mathrm{g} / \mathrm{mL}$ (Figure 12) but decreased almost linearly when desorption using $1.0 \mathrm{M}$ of $\mathrm{HCl}$ is performed at $2000 \mu \mathrm{g} / \mathrm{mL}$ and $4000 \mu \mathrm{g} / \mathrm{mL}$ treatment groups (Figure 12B).

To fully desorb the $\mathrm{Pb}(\mathrm{II})$ ions at 2000 and $4000 \mu \mathrm{g} / \mathrm{mL}$, $\mathrm{HCl}$ concentrations may need to be increased to recover the equivalent amount of $\mathrm{Pb}(\mathrm{II})$ ions adsorbed from the biomass since the degree of desorption activity is dependent on the ratio between the desorbing eluent (liquid phase) and the sorbent-sorbate complex (solid phase) (Chatterjee and Abraham, 2019). This is supported by the studies of Kariuki et al. (2016), and Akhtar et al. (2004) wherein increasing concentrations of $\mathrm{HCl}$ enhances the desorption capacity of $\mathrm{HM}$ in higher HM concentrations. However, higher concentrations of $\mathrm{HCl}$ can degrade immobilized biological tissues leading to a loss in biomass and biosorption capacity which can drastically decrease the biosorbent's degree of reusability for repeated use (Hammaini et al., 2007).

\section{Conclusion}

Moringa oleifera proved to be a suitable substrate for the immobilization of T. macrosporus and the generation of fungiwood biosorbents which successfully adsorbed $\mathrm{Pb}(\mathrm{II})$ at 1000 , 2000, and $4000 \mathrm{ug} / \mathrm{mL}$, as measured through ICP-AES. Minimal amounts $(0.0 .16 \pm 0.016 \mathrm{~g})$ of $T$. macrosporus colonizing the wood $(\mathrm{WP}+\mathrm{F})$ was enough to remove $91-95 \%$ of $\mathrm{Pb}(\mathrm{II})$ in the test solutions and significantly increase its biosorption capacity for all $\mathrm{Pb}$ (II) concentrations in 30 minutes. The sorptive ability of non-immobilized fungal biomass (F) and $\mathrm{WP}+\mathrm{F}$ were found to be similar, but the latter is more efficient for greater biomass generation. Powdered biomass (WP and $\mathrm{WP}+\mathrm{F}$ ) act as significantly better biosorbents for $\mathrm{Pb}(\mathrm{II})$ binding compared to whole (WW, WW+F). The significantly higher and continued $\mathrm{Pb}(\mathrm{II})$ uptake of $\mathrm{WP}+\mathrm{F}$ compared to WP regardless of starting metal concentration may be attributed to the unsaturation or difference in the number, type, and distribution of binding sites in the fungal and/or plant cell walls exposed to the metal fraction, as suggested by previous studies. FTIR Analysis showed hydroxyl, carboxyl, amine, and aromatic groups which may participate in the $\mathrm{Pb}$ (II) sorption process. The resulting $\mathrm{Pb}$ (II) uptake of $\mathrm{WP}+\mathrm{F}$ from the contact test identical to the removal in the CF setup shows that the biosorbent can be used for both a CF and open system without compromising adsorption ability. The recovery of $\mathrm{Pb}$ (II) from acid treated biosorbent proves $\mathrm{Pb}$ (II) entrapment in the WP+F matrix, being able to trap as much as $99.61 \%$ of all available ions in the aqueous solution. The results of this work can be considered for potential applications and design of biotreatment methodologies for $\mathrm{Pb}(\mathrm{II})$-contaminated wastewaters.

\section{Author Contributions}

ZAN Maini is the project leader who was responsible for overseeing the entire work, drafting the manuscript and assisting in all the experiments performed. NTB Flores and EP Muñoz were responsible for performing all experiments found in the study. Additionally, NTB Flores was primarily responsible for the statistical analysis, while EP Muñoz was primarily responsible for sample collection and preparation of the biosorbent.

\section{Acknowledgements}

This research was partly supported by the Ateneo de Manila School of Science and Engineering and Loyola Schools Sanggunian Student Assistance Subsidy and the University Research Council under grant URC-16-12. The authors would like to thank Dr. rer. nat Crisanto M. Lopez and Ms. Pia Clarisse R. Gulpeo for their comments and suggestions as well as the Materials Science Laboratory of the Department of Physics of the Ateneo de Manila University for the use of their SEM. Finally, the authors express their gratitude to Ms. Bin Jeremiah Barba, Mr. Alvin Gallardo and Dr. Carlo Arcilla of the Philippine Nuclear Research Institute for the use of their ATR-FTIR. The authors would like to thank the Loyola Schools Office of the Associate Dean for Research and Creative Work and the Rizal Library Open Access Journal Publication Grant for funding the publication of this work.

\section{Conflict of Interest Declaration}

The authors have no conflict of interest in the research reported here.

\section{References}

Ahluwalia, S.S. and Goyal, D., 2007. Microbial and plant derived biomass for removal of heavy metals from wastewater. Bioresource Technology, 98(2007), 2243-2257. https://doi.org/10.1016/j.biortech.2005.12.006

Akar T, Tunali S and Cabuk A., 2007. Study on the Characterization of Lead (II) Biosorption by Fungus Aspergillus parasiticus. Applied Biochemistry and Biotechnology, 136, 389-406. https://doi.org/10.1007/s12010-007-9032-8

Akar, T., Tunali, S. and Kiran, I., 2005. Botrytis cinereal as a new fungal biosorbent for removal of $\mathrm{Pb}$ (II) from aqueous solutions. Biochemical Engineering Journal, 25(3), 227-235. https://doi.org/10.1016/j.bej.2005.05.006 
Akhtar, N., Iqbal, J. and Iqbal, M., 2004. Removal and recovery of nickel (II) from aqueous solution by loofa spongeimmobilized biomass of Chlorella sorokiniana: characterization studies. Journal of Hazardous Materials, 85-94. https://doi.org/10.1016/j.jhazmat.2004.01.002

Anwar, F., Latif, S., Ashraf, M. and Gilani, A.H., 2007. Moringa oleifera: a food plant with multiple medicinal uses. Phytotherapy Research, 21, 17-25. https://doi.org/10.1002/ptr.2023

Assi, M.A., Hezmee, M.N., Haron, A.W., Sabri, M.Y. and Rajion, M.A., 2016. The detrimental effects of lead on human and animal health. Veterinary World, 9(6), 660-671. https://doi.org/10.14202/vetworld.2016.660-671

Ayangbenro, A.S., and Babalola, O.O., 2017. A new strategy for heavy metal polluted environments: A review of microbial biosorbents. International Journal of Environmental Research and Public Health, 14(1), 1-16. https://doi.org/10.3390/ijerph14010094

Aytar, P., Gedikli, S., Buruk, Y., Cabuk, A. and Burnak, N., 2014. Lead and nickel biosorption with a fungal biomass isolated from metal mine drainage: Box-Behnken experimental design. International Journal of Environmental Science and Technology, 11(6), 1631-1640. https://doi.org/10.1007/s13762-013-0354-5

Basra, S., Iqbal, Z., Rehman, K., Rehman, H. and Ejaz, M.F., 2014. Time course changes in $\mathrm{pH}$, electrical conductivity and heavy metals $(\mathrm{Pb}, \mathrm{Cr})$ of wastewater using Moringa oleifera Lam. Seed and alum, a comparative evaluation. Journal of Applied Research and Technology, 12(3), 560-567. https://doi.org/10.1016/S1665-6423(14)71635-9

Cai, C.X., Xu, J., Deng, N.F., Dong, X.W., Tang, H., Liang, Y., Fan, X.W. and Li, Y.Z., 2016. A novel approach of utilization of the fungal conidia biomass to remove heavy metals from the aqueous solution through immobilization. Scientific Reports, 6(36546), 1-12. https://doi.org/10.1038/srep36546

Chatterjee, A. and Abraham, J., 2019. Desorption of heavy metals from metal loaded sorbents and e-wastes: A review. Biotechnology Letters, 41(3), 319-333.

https://doi.org/10.1007/s10529-019-02650-0

Chen, B., Yuan, M., and Liu, H., 2011. Removal of polycyclic aromatic hydrocarbons from aqueous solution using plant residue materials as a biosorbent. Journal of Hazardous Materials, 188(1-3), 436-442. https://doi.org/10.1016/j.jhazmat.2011.01.114

Cui, H., Li, F., Ren, B., Xue, C., Cui, C., and Wang, J., 2017. Biosorption of aquatic $\mathrm{Pb} 2, \mathrm{Hg} 2$, and $\mathrm{Cd} 2$ using a combined biosorbent - Aspergillus niger-Treated Rice Straw. Separation Science and Technology, 53(4), 626-635. https://doi.org/10.1080/01496395.2017.1412463

Das, M., and Adholeya, A., 2015. Potential Uses of Immobilized Bacteria, Fungi, Algae, and Their Aggregates for Treatment of Organic and Inorganic Pollutants in Wastewater. ACS Symposium Series Water Challenges and Solutions on a Global Scale, 319-337. https://doi.org/10.1021/bk-2015-1206.ch015

Deng, L., Su, Y., Su, H., Wang, X., and Zhu, X., 2006. Biosorption of copper (II) and lead (II) from aqueous solutions by nonliving green algae Cladophora fascicularis: Equilibrium, kinetics and environmental effects. Adsorption,12(4), 267277.

https://doi.org/10.1007/s10450-006-0503-y
Dhankhar, R. and Hooda, A., 2011. Fungal biosorption - an alternative to meet the challenges of heavy metal pollution in aqueous solutions. Environmental Technology, 32(5), 467491. https://doi.org/10.1080/09593330.2011.572922

Ding, H., Luo, X., Zhang, X. and Yang, H., 2019. Alginateimmobilized Aspergillus niger: Characterization and biosorption removal of thorium ions from radioactive wastewater. Colloids and Surfaces A: Physicochemical and Engineering Aspects, 562, 186-195. https://doi.org/10.1016/j.colsurfa.2018.11.032.

Evans, P., Michell, A. and Schmalzl, K., 1992. Studies of the degradation and protection of wood surfaces. Wood Science and Technology,26(2), 151-163. https://doi.org/10.1007/bf00194471

Fahey, L.M., Nieuwoudt, M.K. and Harris, P.J., 2017. Predicting the cell-wall compositions of Pinus radiata (radiata pine) wood using ATR and transmission FTIR spectroscopies. Cellulose, 24(12), 5275-5293. https://doi.org/10.1007/s10570-017-1506-4

Faix, O., 1991. Classification of Lignins from Different Botanical Origins by FT-IR Spectroscopy. Holzforschung, 45(S1), 2128. https://doi.org/10.1515/hfsg.1991.45.s1.21

Fan, T., Liu, Y., Feng, B., Zeng, G., Yang, C., Zhou, M. and Wang, X., 2008. Biosorption of cadmium(II), zinc(II) and lead(II) by Penicillium simplicissimum: Isotherms, kinetics and thermodynamics. Journal of Hazardous Materials, 160(23), 655-661. https://doi.org/10.1016/j.jhazmat.2008.03.038.

Galgoczy, L., Yap, A., and Marx, F., 2019. Cysteine-Rich Antifungal Proteins from Filamentous Fungi are Promising Bioactive Natural Compounds in Anti-Candida Therapy. Israel Journal of Chemistry, 59(5), 360-370. https://doi.org/10.1002/ijch.201800168

Ge, Y. and Li, Z., 2018. Application of Lignin and Its Derivatives in Adsorption of Heavy Metal Ions in Water: A Review. ACS Sustainable Chemistry and Engineering, 6(5), 7181-7192. https://doi.org/10.1021/acssuschemeng.8b01345

Goyari, S., Devi, S., Bengyella, L., Khan, M., Sharma, C.K., Kalita, M.C., and Talukdar, N.C., 2015. Unveiling the optimal parameters for cellulolytic characteristics of Talaromyces verruculosus SGMNPf3 and its secretory enzymes. Journal of Applied Microbiology, 119(1), 88-98. https://doi.org/10.1111/jam.12816

Gube, M., 2016. Fungal Molecular Response to Heavy Metal Stress. In: Esser, K., Hoffmeister, D. (eds) Biochemistry and Molecular Biology. The Mycota (A Comprehensive Treatise on Fungi as Experimental Systems for Basic and Applied Research) vol III (pp. 47-68), Cham, Switzerland: Springer. https://doi.org/10.1007/978-3-319-27790-5_4

Hammaini, A., Gonzales, F., Ballester, A., Blazquez M.L. and Munoz, J.A., 2007. Biosorption of heavy metals by activated sludge and their desorption characteristics. Journal of environmental Management, 84, 419-426. https://doi.org/10.1016/j.jenvman.2006.06.015

Hauptman, M., Bruccoleri, R. and Woolf, A.D., 2017. An Update on Childhood Lead Poisoning. Clinical Pediatric Emergency Medicine, 18(3), 181-192. https://doi.org/10.1016/j.cpem.2017.07.010. 
Higgins, H.G., Stewart, C.M., and Harrington, K.J., 1961. Infrared spectra of cellulose and related polysaccharides. Journal of Polymer Science, 51(1), 59-84. https://doi.org/10.1002/pol.1961.120510105

Iqbal, M. and Edyvean, R.G., 2004. Biosorption of lead, copper and zinc ions on loofa sponge immobilized biomass of Phanerochaete chrysosporium. Minerals Engineering, 17, 217-223. https://doi.org/10.1016/j.mineng.2003.08.014

Iqbal, M. and Saeed, A., 2006. Entrapment of fungal hyphae in structural fibrous network of papaya wood to produce a unique biosorbent for the removal of heavy metals. Enzyme and Microbial Technology, 39, 996-1001. https://doi.org/10.1016?j.enzmictec.2006.02.019

Iram, S., Shabbir, R., Zafar, H., and Javaid, M., 2015. Biosorption and Bioaccumulation of Copper and Lead by Heavy MetalResistant Fungal Isolates. Arabian Journal for Science and Engineering, 40(7), 1867-1873. https://doi.org/10.1007/s13369-015-1702-1

Janusz, G., Pawlik, A., Sulej, J., Swiderska-Burek, U., JaroszWilkolazka, A. and Paszczynski, A., 2017. Lignin degradation: microorganisms, enzymes involved, genomes analysis and evolution. FEMS Microbiology Reviews, 41(6), 941962.

https://doi.org/10.1093/femsre/fux049

Jha, S., Chauhan, R. and Dikshit, S.N., 2014. Fungal biomass as biosorbent for removal of heavy metal from industrial wastewater effluent. Asian Journal of Plant Sciences, 13(2), 93-97.

https://doi.org/10.3923/ajps.2014.93.97

Jin, W.J., Singh, K., Zondlo, J., Wang, J.X. and Brar, J., 2012. Pyrolysis kinetics of physical components of wood and woodpolymers using isoconversion method. Agriculture, 3, 12-32. https://doi.org/10.3390/agriculture3010012

Kapoor, A. and Viraraghavan, T., 1995. Fungal biosorption - an alternative treatment option for heavy metal bearing wastewaters: A review. Bioresource Technology, 53(1995), 195-206. https://doi.org/10.1016/0960-8524(95)00072-M

Kariuki, Z., Kiptoo, J. and Onyancha, D., 2016. Biosorption of lead and copper using rogers mushroom biomass 'Lepiota hystrix'. South African Journal of Chemical Engineering, 23, $62-70$. https://doi.org/10.1016/j.sajce.2017.02.001

Li, X., Liao, D., Xu, X., Yang, Q., Zeng, G., Zheng, W., and Guo, L., 2008. Kinetic studies for the biosorption of lead and copper ions by Penicillium simplicissimum immobilized within loofa sponge. Journal of Hazardous Materials, 159(23), 610-615. https://doi.org/10.1016/j.jhazmat.2008.02.068

Liang, C. Y., and Marchessault, R. H., 1959. Infrared spectra of crystalline polysaccharides. II. Native celluloses in the region from 640 to $1700 \mathrm{~cm}$.1. Journal of Polymer Science, 39(135), 269-278. https://doi.org/10.1002/pol.1959.1203913521

Long, J., Yuvaraja, G., Zhou, S., Mo, J., Li, H., Luo, D.. and Reddy, G. M, 2019. Inactive Fusarium Fungal strains (ZSY and MJY) isolation and application for the removal of $\mathrm{Pb}$ (II) ions from aqueous environment. Journal of Industrial and Engineering Chemistry, 72, 442-452. https://doi.org/10.1016/j.jiec.2018.12.047

Maini, Z.A.N., Aribal, K.M., Narag, R.M., Melad, J.K.L., Frejas, J.A., Arriola, L.A., Gulpeo, P.C., I.A. and Lopez, C., 2019.
Lead (II) tolerance and uptake capacities of fungi isolated from a polluted tributary in the Philippines. Applied Environmental Biotechnology, 4(1), 18-29. https://doi.org/10.26789/AEB.2019.01.004

Malik, D.S., Jain, C.K., and Yadav, A.K., 2016. Removal of heavy metals from emerging cellulosic low-cost adsorbents: A review. Applied Water Science, 7(5), 2113-2136. https://doi.org/10.1007/s13201-016-0401-8

Mataka, L.M., Henry, E.M., Masamba, W.R. and Sajidu, S.M., 2006. Lead remediation of contaminated water using Moringa stenopetala and Moringa oleifera seed powder. International Journal of Environmental Science and Technology, 3(2), 131-139. https://doi.org/10.1007/bf03325916

Michalak, I., Chojnacka, K. and Krowiak, AW., 2013. State of the art for the biosorption process - a review. Applied Biochemistry and Biotechnology, 170, 1389-1416. https://doi.org/10.1007/s12010-013-0269-0

Mirzabeygi, M., Abbasnia, A., Yunesian, M., Nodehi, RN., Yousefi, N., Hadi, M. and Mahvi, AH., 2017. Heavy metal contamination and health risk assessment in drinking water of Sistan and Baluchistan, Southeastern Iran. Human and Ecological Risk Assessment: An International Journal, 23(8), 1893-1905. https://doi.org/10.1080/10807039.2017.1322895

Mohaček-Grošev, V., Božac, R., and Puppels, G.J., 2001. Vibrational spectroscopic characterization of wild growing mushrooms and toadstools. Spectrochimica Acta Part A: Molecular and Biomolecular Spectroscopy, 57(14), 2815-2829. https://doi.org/10.1016/s1386-1425(01)00584-4

Morin-Crini, N., Loiacono, S., Placet, V., Torri, G., Bradu, C., Kostić, M., Cosentino, C., Chanet, G., Martel, B., Lichtfouse, E. and Crini, G., 2018. Hemp-based adsorbents for sequestration of metals: A review. Environmental Chemistry Letters, 17(1), 393-408. https://doi.org/10.1007/s10311-018-0812-x

Naumann, A., 2015. Fourier Transform Infrared (FTIR) Microscopy and Imaging of Fungi. Fungal Biology Advanced Microscopy in Mycology, 61-88. https://doi.org/10.1007/978-3-319-22437-4_4

Naumann, A., Navarro-González, M., Peddireddi, S., Kües, U., and Polle, A., 2005. Fourier transform infrared microscopy and imaging: Detection of fungi in wood. Fungal Genetics and Biology, 42(10), 829-835. https://doi.org/10.1016/j.fgb.2005.06.003

Njoki, M.A., Mercy, G., Nyagah, G. and Gachanja, A., 2016. Fourier transform infrared spectrophotometric analysis of functional groups found in Ricinus communis L. and Cucurbita maxima LAM. Roots, stems and leaves as heavy metal adsorbents. International Journal of Science, Environment and Technology, 5(3), 861-871. https://www.ijset.net/journal/944.pdf

Obuseng, V., Nareetsile, F. and Kwaambwa, H.M., 2012. A study of the removal of heavy metals from aqueous solutions by Moringa oleifera seeds and amine-based ligand 1,4-bis[N,Nbis(2-picoyl)amino]butane. Analytica Chimica Acta, 730, 87-92. https://doi.org/10.1016/j.aca.2012.01.054

Pagnanelli, F., Viggi, C., Mainelli, S. and Toro, L., 2009. Assessment of solid reactive mixtures for the development of biological permeable reactive barriers. Journal of Hazardous 
Materials, 170(2-3), 998-1005.

https://doi.org/10.1016/j.jhazmat.2009.05.081

Putra, W.P., Kamari, A., Yusoff, S.N., Ishak, C.F., Mohamed, A., Hashim, N., and Isa, I.M., 2014. Biosorption of $\mathrm{Cu}(\mathrm{II}), \mathrm{Pb}(\mathrm{II})$ and $\mathrm{Zn}$ (II) Ions from Aqueous Solutions Using Selected Waste Materials: Adsorption and Characterisation Studies. Journal of Encapsulation and Adsorption Sciences,04(01), 25-35. https://doi.org/10.4236/jeas.2014.41004

Ramrakhiani, L., Ghosh, S. and Majumdar, S., 2016. Surface Modification of Naturally Available Biomass for Enhancement of Heavy Metal Removal Efficiency, Upscaling Prospects, and Management Aspects of Spent Biosorbents: A Review. Applied Biochemistry and Biotechnology,180(1), 41-78. https://doi.org/10.1007/s12010-016-2083-y

Reddy, D. H., Harinath, Y., Seshaiah, K., and Reddy, A., 2010. Biosorption of $\mathrm{Pb}$ (II) from aqueous solutions using chemically modified Moringa oleifera tree leaves. Chemical Engineering Journal, 162(2), 626-634. https://doi.org/10.1016/j.cej.2010.06.010

Sağ, Y., 2001. Biosorption of heavy metals by fungal biomass and modeling of fungal biosorption: A review. Separation and Purification Methods, 30(1), 1-48. https://doi.org/10.1081/SPM-100102984

Saravanan, R., and Ravikumar, L., 2015. The Use of New Chemically Modified Cellulose for Heavy Metal Ion Adsorption and Antimicrobial Activities. Journal of Water Resource and Protection, 07(6), 530-545. https://doi.org/10.4236/jwarp.2015.76042

Say, R., Y1lmaz, N., and Denizli, A., 2003a. Biosorption of Cadmium, Lead, Mercury, and Arsenic Ions by the Fungus Penicillium purpurogenum. Separation Science and Technology, 38(9), 2039-2053. https://doi.org/10.1081/ss-120020133

Say, R., Yilmaz, N., and Denizli, A., 2003b. Removal of Heavy Metal Ions Using the Fungus Penicillium canescens. Adsorption Science and Technology, 21(7), 643-650. https://doi.org/10.1260/026361703772776420

Shakya, M., Sharma, P., Meryem, S.S., Mahmood, Q., and Kumar, A, 2016. Heavy Metal Removal from Industrial Wastewater Using Fungi: Uptake Mechanism and Biochemical Aspects. Journal of Environmental Engineering, 142(9. https://doi.org/10.1061/(asce)ee.1943-7870.0000983
Sriharsha, D.V., Lokesh, K.R. and Savitha, J., 2017. Immobilized fungi on Luffa cylindrica: An effective biosorbent for the removal of lead. Journal of the Taiwan Institute of Chemical Engineers, 80, 589-595. https://doi.org/10.1016/j.jtice.2017.08.032

Stohs, S.J. and Hartman, M.J., 2015. Review of the safety and efficacy of Moringa oleifera. Phytotherapy Research, 29(6), 796-804. https://doi.org/10.1002/ptr.5325

Svobodova, K. and Novotny, C., 2018. Bioreactors based on immobilized fungi: bioremediation under non-sterile conditions. Applied Microbiology and Biotechnology, 102(1), 39-46. https://doi.org/10.1007/s00253-017-8575-Z

Traoré, M., Kaal, J. and Cortizas, A.M., 2017. Differentiation between pine woods according to species and growing location using FTIR-ATR. Wood Science and Technology,52(2), 487-504. https://doi.org/10.1007/s00226-017-0967-9

Velkova, Z., Kirova, G., Stoytcheva, M., Kostadinova, S., Todorova, K. and Gochev, V., 2018. Immobilized microbial biosorbents for heavy metals removal. Engineering in Life Sciences, $18,871-881$. https://doi.org/10.1002/elsc.201800017

Wong, D., Merrifield-Macrae, M. and Stillman, M., 2017. Lead(II) binding in metallothioneins. Metal Ions in Life Sciences, 17, 241-269. https://doi.org/10.1515/9783110434330-009

Yang, Y., Yan, Z., Wang, L., Meng, Q., Yuan, Y. and Zhu, G., 2018. Constructing synergistic groups in porous aromatic frameworks for the selective removal and recovery of lead(ii) ions. Journal of Materials Chemistry A, 6(12), 5202-5207. https://doi.org/10.1039/c8ta00382c

Zahmatkesh, M., Spanjers, H. and van Lier, J.B., 2018. A novel approach for application of white rot fungi in wastewater treatment under non-sterile conditions: immobilization of fungi on sorghum. Environmental Technology, 39(16), 20302040. https://doi.org/10.1080/09593330.2017.1347718

Zhao, G., Liu, X., Ren, S., Tan, W. and Fang, G., 2018. Quantitative comparison of surface properties of enzymatic hydrolysis lignin before and after degradation. Industrial Crops and Products, $125,468-472$. https://doi.org/10.1016/j.indcrop.2018.09.020 